THE ROLE OF PRO-INFLAMMATORY

NEUROPEPTIDES IN ULCERATIVE COLITIS

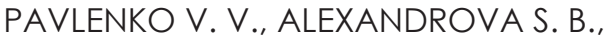

TSUROVA E. A., AMIRKHANOVA L. Z.

The study included 40 patients with ulcerative colitis during the treatment with various drug combinations. Serum levels of neuropeptides were measured with ELISA assay.

It was found that during the exacerbation of ulcerative colitis the substance P (SP) is increased in serum, while there is a decrease in neurotensin serum levels. SP serum levels were in direct correlation with the severity of the disease under discussion, and the NT serum levels demonstrated inverse correlation.

Drugs used in the treatment schemes for ulcerative colitis are able to modulate the serum levels of neuropeptides under consideration in patients with active ulcerative colitis.

Key words: ulcerative colitis, neuropeptides

\section{РОАЬ ПРОВОСПААИТЕАЬНЫХ}

НЕЙРОПЕПТИАОВ ПРИ ЯЗВЕННОМ КОАИТЕ

В. В. ПАВАEHKO, С. Б. A^ЕКСАHАPOBA,

Е. А. ЦУРОВА, ^. 3. АМИРХАНОВА

Обследованы 40 пациентов с язвенным колитом в динамике лечения различными комбинациями лекарственных препаратов. Содержание нейропептидов в сыворотке крови определяли методом иммуноферментного анализа.

Установлено, что в период обострения язвенного колита содержание вещества Р в сыворотке крови повышено, а уровень нейротензина снижен. Содержание SP в сыворотке крови находилось в прямой зависимости от тяжести заболевания, а уровень NT - в обратной.

Используемые в терапии язвенного колита лекарственные препараты способны модулировать уровень изучаемых нейропептидов в сыворотке крови больных активным язвенным колитом.

Ключевые слова: язвенный колит, нейропептиды

\title{
INTRACELLULAR ADHESION MOLECULES AND HISTOLOGICAL PATTERN IN CHRONIC VIRAL LIVER DISEASES
}

\author{
Koroy P. V., Mukhoramova I. S., Yagoda A. V.
}

\section{Stavropol State Medical University, Russian Federation}

AN imbalance between fibrogenesis and fibrolysis that develops as a result of excessive production of extracellular matrix molecules, reduced expression of tissue metalloproteinases, and an increase in their inhibitors' synthesis in stellate cells leads to hepatic fibrosis $[7,19]$, and, in case of its progression - to hepatic cirrhosis, disruption of the relationship between the hepatocytes metabolism and the hepatic vascular bed [15].

Given the crucial role of the endothelium in the development of inflammatory and immune responses, the link between intracellular adhesion molecules and morphological changes in the liver appears a logic one. Leukocytes and sinusoidal cells interactions are involved into the pathogenesis of acute liver damage, while the immuno-

Koroy Pavel, MD, PhD, Professor, Department of Hospital Therapy, Stavropol State Medical University tel.: 9282938068, e-mail: paule75@yandex.ru

Mukhoramova Irina, MD, Gastroenterology Department, Stavropol Regional Centre for Specialized Medical Assistance; tel.: 9054484141

Yagoda Alexander, MD, PhD, Professor, Head

of Department of Hospital Therapy, Stavropol State Medical University; tel.: 89064907330, e-mail: alexander.yagoda@gmail.com globulin superfamily plays a key role in the noted intracellular reactions $[13,21]$. Thus, in the model of endotoxin-induced liver injury, an increase in the expression of the intercellular adhesion molecule type 1 (ICAM-1) and the vascular cell adhesion molecule type 1 (VCAM-1) in sinusoidal cells caused increased neutrophil infiltration in liver sinusoids, whereas concanavalin-induced hepatitis taken against the ICAM-1 deficiency, on the contrary, could be characterized with the minimal evidence of liver necrosis and low aminotransferase activity [8]. There has been positive correlation noticed for TNF- $\alpha$ mRNA expression in liver with tissue expression of ICAM-1 and VCAM-1 mRNAs in patients with hepatic cirrhosis [12].

In case of moderate and severe morphological signs of chronic viral hepatitis $(\mathrm{CVH})$, there are relatively higher plasma and tissue concentrations of ICAM-1 and VCAM-1 [1, 5, 20], which were in positive correlation with the histological activity index $[1,3,5,6]$. A progression of hepatic fibrosis against the $\mathrm{HCV}$ infection was associated with a significant increase in ICAM-1 and VCAM-1 blood concentrations and direct relationship of the mediators' profiles with the hepatitis stage $[2,5,6]$. There is also an opposite viewpoint available, which 
claims no connection between the VCAM-1 level and the severity of inflammation [3, 9] and fibrosis in patients with $\mathrm{CVH}$ [9].

Therefore, the immunoglobulin superfamily members are involved in the inflammatory response, fibrogenesis, and tissue remodeling in liver. However, the association of adhesion molecules with the histological activity and the stage of the disease has not been clarified, just like there has been no precise specification as to their role as noninvasive markers of histological activity and hepatic fibrosis.

The purpose of the study was to establish the interrelation between the intercellular interactions mediators and the histological features in chronic viral liver pathology.

Material and Methods. The study covered 41 patients with chronic viral hepatitis and 9 patients with hepatic cirrhosis (25 males and 25 females) aged 24-56. The control group included 16 healthy volunteers in the age range of 22-55. All the patients had their Knodell and Desmet indices scored. The histological activity index ( $\mathrm{HAl})$ in the cases with chronic hepatitis scored $8.34 \pm 0.52$, the fibrosis index $(\mathrm{FI})-1.83 \pm 0.13$. In the group with hepatic cirrhosis these Figures were 10.44 \pm 1.04 (HAI) and $3.89 \pm 0.11(\mathrm{FI})$. Hepatic steatosis, assessed employing E.M. Brunt's method, was detected in $70 \%$ of the patients; in most cases the fatty liver infiltration was of minimum degree (62.9\%).

The serum levels of ICAM-1 and VCAM-1 were studied through the EIA method employing the «Bender MedSystems $\mathrm{GmbH}$ » kits (Austria) following the instructions attached.

The results went through statistic processing. The quantitative characteristics, described with nonnormal distribution, are presented as a median and an interquartile range. The Kruskal-Wallis test with Dunn's multiple comparison was used to detect the intra- and intergroup differences. Spearman's rank correlation coefficient ( $r s$ ) was also calculated. To determine the prognostic role of a feature there was calculation done in relation to the odds ratio (OR) with the calculation of a $95 \%$ confidence interval. The features' diagnostic value was determined based on their sensitivity, specificity, positive or negative predictive potency, and accuracy, which were expressed as percentage. The differences with $p \leq 0.05$ were considered significant.

Results and Discussion. In case of chronic viral hepatitis there was an increase in the blood concentration of intercellular adhesion molecule type 1 , while the serum levels of VCAM-1 remained within norm. The patients with hepatic cirrhosis revealed higher indices in both adhesion molecules, which were significantly higher if compared to the cases with chronic hepatitis.

The ICAM-1 and VCAM-1 blood levels went up along an increase in the fatty liver infiltration and peaked in case of grade 2 steatosis, while being significantly different from the corresponding values in the patients with no or minimal steatosis.
There was a significant positive correlation found between ICAM-1 and VCAM-1 on the one hand, and the hepatic steatosis degree, on the other ( $r s=$ $0.68 ; r s=0.36 ; p<0.05$ ).

In patients with moderate and high histological activity of chronic viral hepatitis the ICAM- 1 and VCAM-1 blood concentrations were higher and exceeded significantly those in patients with minimal morphological manifestations. The patients with chronic viral hepatitis, who scored $\mathrm{HAl} \leq 8$, showed an increase in ICAM-1 alone (Table 1). The correlation of ICAM-1 and the intensity of the inflammatory changes in the liver was positive ( $r s=0.48 ; p<0.05)$.

Link between adhesion molecules and the intensity of the inflammatory component in chronic viral liver diseases (Me (Q1-Q3)

\begin{tabular}{|c|c|c|c|}
\hline \multirow{2}{*}{ Groups studied } & \multicolumn{2}{|c|}{ Factors under investigation } \\
\cline { 2 - 4 } & ICAM-1 $(\mathrm{ng} / \mathrm{ml})$ & VCAM-1 $(\mathrm{ng} / \mathrm{ml})$ \\
\hline \multicolumn{2}{|c|}{ Healthy } & $257.5(150-338)$ & $2500(1625-3425)$ \\
\hline \multirow{3}{*}{ Impaired } & HAI $\leq 8$ & $360(299-421) *$ & $1850(1100-3700)$ \\
\cline { 2 - 4 } & HAI $>8$ & $\begin{array}{c}626(421-790) \\
* / * *\end{array}$ & $\begin{array}{c}3700(2148-5600) \\
* / * *\end{array}$ \\
\hline
\end{tabular}

${ }^{*} \mathrm{p}<0.05$ when compared with the healthy;

** $p<0.05$ when compared with $\mathrm{HAl} \leq 8$

The ICAM-1 $\geq 462.0 \mathrm{ng} / \mathrm{ml}$ (OR: 6.2 (1.8-21.9)) and VCAM-1 $\geq 1900 \mathrm{ng} / \mathrm{ml}$ (OR: 7.5 (1.9-29.9)) were associated with an increased risk of HAl scoring above 8 in patients with chronic viral hepatitis. The above values showed moderate diagnostic accuracy $(72.0 \%$ and $74.0 \%$ respectively) in detecting $\mathrm{HAl}$ exceeding 8.

The ICAM-1 and VCAM-1 serum levels, while going up along with the growth of fibrotic changes in the liver, reached its peak at the fibrosis index of 3-4. At this stage of fibrosis the vascular cell adhesion molecule type 1 levels were significantly higher than in patients with $\mathrm{CVH}$ their Desmet index scoring 0-1 and 2 (Table 2). In the cases of absence/minimal or moderate hepatic fibrosis the ICAM-1 values were found elevated, and the VCAM1 values - normal. There was a positive correlation found between ICAM- 1 and VCAM- 1 on the one hand, and the fibrosis index on the other ( $r s=0.33$; $r s=0.60 ; r s=0.43 ; p<0.05$ ).

Table 2

Connection between adhesion molecules and hepatic fibrosis in chronic viral liver diseases (Me (Q1-Q3)

\begin{tabular}{|c|l|c|c|}
\hline \multicolumn{2}{|c|}{ Groups studied } & \multicolumn{2}{|c|}{ Factors under investigation } \\
\cline { 2 - 4 } & ICAM-1 (ng/ml) & $\begin{array}{c}\text { VCAM-1 } \\
(\mathrm{ng} / \mathrm{ml})\end{array}$ \\
\hline \multirow{4}{*}{ Healthy } & $257.5(150-338)$ & $\begin{array}{c}2500 \\
(1625-3425)\end{array}$ \\
\cline { 2 - 4 } Impaired & Stage F 0-I & $421(362-500) *$ & $\begin{array}{c}2050 \\
(950-2500)\end{array}$ \\
\cline { 2 - 4 } & Stage F II & $\begin{array}{c}462(327.5- \\
601.5) *\end{array}$ & $\begin{array}{c}2550 \\
(1700-3100)\end{array}$ \\
\cline { 2 - 4 } & Stage F III- & $655(355-950) *$ & $\begin{array}{c}5825 \\
(4500-11250) \\
* / * * / * * *\end{array}$ \\
\hline
\end{tabular}

${ }^{*} p<0.05$ when compared with the healthy.

${ }_{* \star} p<0.05$ when compared with F0-I;

$\star \star \star x<0.05$ when compared with FII 
The patients with ICAM- $1 \geq 626.0 \mathrm{ng} / \mathrm{ml}$ (OR: 4.7 (1.4-16.3)) and VCAM- $1 \geq 3980 \mathrm{ng} / \mathrm{ml}$ (OR: 21.7 (4.7-99.5)) were stood a greater chance of being diagnosed with severe fibrosis/cirrhosis. The values of VCAM-1 $\geq 3980 \mathrm{ng} / \mathrm{ml}$ revealed a high diagnostic accuracy $(82.0 \%)$ in identifying fibrosis stages III-IV, while the predictive potency of the ICAM-1 values exceeding $626.0 \mathrm{ng} / \mathrm{ml}$ was somewhat lower $(70.0 \%)$.

The data obtained confirm the association between the adhesion molecules and histological changes in chronic viral liver pathology. This comes as quite an expected result in view of the role played by the mediators of intercellular interactions in inflammatory, regenerative and remodeling processes in the liver $[3,8,11,14]$.

The inflammatory process is known to be a cascade of interactions between immune and vascular cells, which depends on the functioning of endothelial cells, these creating a barrier between the blood and the tissues, cleaning the sinusoids of proinflammatory substances, and releasing immune inflammatory modulators. The role of the intercellular adhesion molecule type 1 in intrahepatic inflammation is related to its ligand - lymphocyte function-associated antigen type 1 (LFA-1), which plays a prominent role in the inflammatory liver injury. Thus, in mice model of endotoxin-induced liver injury the deficit of LFA-1 was linked to a reduction in leukocyte adhesion, a decrease in apoptosis, a lower activity of hepatic damage enzymes, and an improved sinusoidal perfusion [10]. Concanavalin-induced cytotoxicity was inhibited through introduction of monoclonal antibodies against ICAM-1/LFA- 1 in vitro and in vivo, while the genetic deficiency of ICAM-1 came accompanied with a decrease in the severity of liver necrosis and a decreased aminotransferases activity [8].

The involvement of VCAM- 1 in the development of hepatic inflammation could be verified through an inhibition of its leukocyte infiltration in the case of using anti-mediator monoclonal antibodies in the setting of concanavalin-induced hepatitis. However, the Concanavalin-induced cytotoxicity was not inhibited with the administration of monoclonal anti-VCAM-1 antibodies both in vitro and in vivo.

Hepatic fibrosis as a result of liver damage manifests after the development of inflammatory process in the organ under consideration. The interactions between stellate cells receptors and extracellular matrix proteins, which are important for the synthesis of collagen and activation of metalloproteinases, are regulated by the adhesion molecules [18].

The involvement of VCAM-1 in hepatic fibrogenesis may be associated with stimulation of the connective tissue growth factor production [3, 18]. Furthermore, under the influence of this mediator, the activated endothelial cells in the space of Disse contribute to the formation of pathological basement membrane in the liver sinusoids [3]. There is a description of correlation between VCAM-1 and procollagen III propeptide, which is a biochemical marker of fibrotic progression [9].

The effect of VCAM-1 and ICAM-1 on hepatic fibrogenesis can be associated with the activating influence of tumor necrosis factor- $\alpha$. Thus, the model of carbon tetrachloride induced liver cirrhosis treated with thalidomide, showed a decrease in mRNA and protein expression of both adhesion molecules in the liver, related to a lower expression of tumor necrosis factor- $\alpha$ and nuclear factor-kB mRNAs and proteins. These changes were accompanied with a decrease in the hepatic fibrosis activity $[11,12,14]$.

Estimation of the activity and fibrosis in chronic viral hepatitis is an important task since its progression leads to the cirrhotic transformation in $1 / 3$ of the patients. Liver biopsy remains the gold standard for assessing the hepatic fibrosis stage, yet it is associated with rare but potentially life-threatening complications [4, 16, 17]. At the same time the accuracy of the histological evaluation of fibrosis is questionable while the imaging techniques lack in sensitivity and specificity in this regard [4].

To conduct noninvasive diagnosis of histological activity and hepatic fibrosis in case of chronic viral pathology, the criterial values for ICAM-1 and VCAM-1 were defined; these had a sufficient diagnostic accuracy in detecting HAl over 8 as well as moderate/severe fibrosis. The ICAM-1 $\geq 462.0 \mathrm{ng} /$ $\mathrm{ml}$ and VCAM-1 $\geq 1900 \mathrm{ng} / \mathrm{ml}$ were linked to a $6.2-$ and 7.5-time increase of detecting $\mathrm{HAl}$ exceeding 8 , while the values of ICAM- $1 \geq 626.0 \mathrm{ng} / \mathrm{ml}$ and VCAM-1 $\geq 3980 \mathrm{ng} / \mathrm{ml}$ brought up the chances $(4.7$ and 21.7 times respectively) of diagnosing moderate/severe fibrosis.

It is quite obvious that defining the intercellular interactions mediators profiles in patients with chronic viral liver issues allows not only establishing the severity of morphological changes, but also stratifying the patients into groups of different histological activity and hepatic fibrosis, which is important in terms of differential diagnosis and prognosis assessment.

\section{Conclusion}

1. Chronic viral hepatitis cases show increased blood levels of intercellular adhesion molecule type 1 , while patients with hepatic cirrhosis reveal increased serum levels of both ICAM-1 and VCAM-1.

2. In case of chronic viral liver pathology the blood level of ICAM-1 and VCAM-1 grows along with the severity of hepatic steatosis, inflammation and fibrosis.

3. Association of morphological manifestations with mediators of intercellular interactions is a proof to their important role in the onset and progression of chronic viral liver diseases. 


\section{References}

1. Abdalla A., Sheesha A. A., Shokeir M. et al. Serum intercellular adhesion molecule-1 in children with chronic liver disease: relationship to disease activity. Dig. Dis. Sci. 2002;47(6):1206-1208.

2. Abdallah N., Morsi M., Hamed N., Abdel Aziz H. Evaluation of prognostic value of cell adhesion molecules in chronic hepatitis C therapy. J. Venom. Anim. Toxins. Incl. Trop. Dis. 2010;16(3):442-448.

3. Bruno C. M., Sciacca C., Cilio D. et al. Circulating adhesion molecules in patients with virus-related chronic diseases of the liver. World. J. Gastroenterol. 2005;11(29):4566-4569.

4. Castera L., Pawlotsky J.-M. Noninvasive diagnosis of liver fibrosis in patients with chronic hepatitis C. Med. Gen. Med. 2005. - Vol. 7 (4). - P. 39-45.

5. De Castro, I.F. Hepatitis $\mathrm{C}$ virus infection is associated with endothelial dysfunction in HIV/hepatitis $\mathrm{C}$ virus coinfected patients / I.F. De Castro, D. Micheloud, J. Berenguer [et al.] // AIDS. - 2010;24(13):2059-2067.

6. El-Shazly M., Yehia Aly N., El-Shimi I. et al. Soluble intercellular adhesion molecule-1 in sera of patients with chronic hepatitis C. Bull. Alexandria. Faculty. Med. 2007;43(4):25-31.

7. Iredale J. P. Models of liver fibrosis: exploring the dynamic nature of inflammation and repair in a solid organ. J. Clin. Invest. 2007;117:539-548.

8. Kawasuji A., Hasegawa M., Horikawa M. et al. L-selectin and intercellular adhesion molecule-1 regulate the development of Concanavalin A-induced liver injury. J. Leukoc. Biol. 2006;79(4):696-705.

9. Kukla M., Zwirska-Korczala K., Gabriel A. et al. Soluble platelet-endothelial cell adhesion molecule-1 and soluble vascular cell adhesion molecule-1: role in pathogenesis and diagnosis of chronic hepatitis $\mathrm{C}$ and association with response to antiviral therapy. Therap. Adv. Gastroenterol. 2009;2(2):79-90.

10. Li X., Klintman D., Weitz-Schmidt G. et al. Lymphocyte function antigen-1 mediates leukocyte adhesion

\section{INTRACELLULAR ADHESION MOLECULES AND HISTOLOGICAL PATTERN IN CHRONIC VIRAL LIVER DISEASES \\ KOROY P. V., MUKHORAMOVA I. S., \\ YAGODA A. $\vee$.}

Serum levels of intercellular adhesion molecule-1 (ICAM-1) and vascular cell adhesion molecule-1 (VCAM-1) were studied in 50 patients with chronic viral liver diseases in view of hepatic histological changes.

The patients with chronic viral hepatitis demonstrated higher levels of intercellular adhesion molecule-1 in the blood while an increase in the serum levels of the two adhesion molecules was observed in the cases with liver cirrhosis.

The blood levels of ICAM- 1 and VCAM- 1 under chronic viral liver diseases increases along with a growing intensity of hepatic steatosis, inflammation and fibrosis. The association of morphological changes in the liver with the mediators of intercellular interactions proves their important role in occurrence and development of chronic viral liver diseases.

Key words: chronic viral hepatitis, liver cirrhosis, intercellular adhesion molecule-1, vascular cell adhesion molecule-1 and subsequent liver damage in endotoxemic mice. Br. J. Pharmacol. 2004;141(4):709-716.

11. Lv P., Luo H. S., Zhou X. P. et al. Reversal effect of thalidomide on established hepatic cirrhosis in rats via inhibition of nuclear factor-kappaB/inhibitor of nuclear factor-kappaB pathway. Arch. Med. Res. 2007;38(1):15-27.

12. Lv P., Paul S. C., Xiao Y. et al. Effects of thalidomide on the expression of adhesion molecules in rat liver cirrhosis. Mediators. Inflamm. 2006;2006(4):932-953.

13. Maeda K., Yoshida K., Ichimiya I., Suzuki M. Dexamethasone inhibits tumor necrosis factor- $\alpha$-induced cytokine secretion from spiral ligament fibrocytes. Hearing Research. 2005;202(1-2):154-160.

14. Paul S. C., Lv P., Xiao Y. et al. Thalidomide in rat liver cirrhosis: blockade of tumor necrosis factor-alpha via inhibition of degradation of an inhibitor of nuclear factor-kappaB. Pathobiology. 2006;73(2):82-92.

15. Pinzani M., Rombouts K. Liver fibrosis: from the bench to clinical targets. Dig. Liver. Dis. 2004;36(4):231-242.

16. Pinzani M., Rombouts K., Colagrande S. Fibrosis in chronic liver diseases: diagnosis and management. J. Hepatol. 2005;42:22-36.

17. Pockros P. J. Noninvasive markers of fibrosis in chronic hepatitis patients. J. Clin. Gastroenterol. 2006;40(6):461-463.

18. Rachwal A. W., Brigstock D. R. Connective tissue growth factor in hepatic fibrosis. Hepatol. Res. 2003;26(1):1-9.

19. Rockey D. C. Antifibrotic therapy in chronic liver disease. Clin. Gastroenterol. Hepatol. 2005;3(2):95-107.

20. Rui-dan Z., Ya-yong S., Yan-hui L. et al. Alteration of intercellular adhesion molecule-1 (ICAM-1) expression in the liver and serum level of HBV DNA in chronic hepatitis B patients after interferon treatment. African. J. Microbiol. Res. 2011;5(10):1211-1214.

21. Woo C.-H., Lim J.-H., Kim J.-H. VCAM-1 upregulation via PKC $\delta$-p38 kinase-linked cascade mediates the TNF- $\alpha$-induced leukocyte adhesion and emigration in the lung airway epithelium. Am. J. Physiol. - Lung Cell. Molecular Physiol. 2005;288(2):307-316.

\section{МОАЕКУАЫ МЕЖКАЕТОЧНОЙ ААГЕЗИИ И ГИСТОАОГИЧЕСКАЯ КАРТИНА ПРИ ХРОНИЧЕСКИХ ВИРУСНЫХ ЗАБОАЕВАНИЯХ ПЕЧЕНИ}

П. В. КОРОЙ, И. С. МУХОРАМОВА, А. В. ЯГГОАА

у 50 больных хроническими вирусными заболеваниями печени изучены сывороточные уровни молекулы межклеточной адгезии 1 типа (ICAM-1) и молекулы адгезии сосудистого эндотелия 1 типа (VCAM-1) во взаимосвязи с гистологическими изменениями в печени.

При хроническом вирусном гепатите отмечается увеличенное содержание молекулы межклеточной адгезии 1 типа в крови, тогда как у пациентов с циррозом печени регистрируется повышение сывороточных значений обеих молекул адгезии. Содержание ICAM-1 и VCAM-1 в крови при хронической вирусной патологии печени увеличивается с ростом тяжести печеночного стеатоза, воспаления и фиброза. Ассоциация морфологических проявлений с медиаторами межклеточных взаимодействий свидетельствует об их важной роли в возникновении и прогрессировании хронической вирусной патологии печени.

Ключевые слова: хронический вирусный гепатит, цирроз печени, молекула межклеточной адгезии 1 типа, молекула адгезии сосудистого эндотелия 1 типа 